\title{
GAMBARAN FAKTOR LINGKUNGAN FISIK RUMAH PENDERITA DBD DI KELURAHAN TELUK KECAMATAN PURWOKERTO SELATAN KABUPATEN BANYUMAS TAHUN 2017
}

\author{
Rahma Widiantari*), Choiroel Anwar**) \\ Jurusan Kesehatan Lingkungan, Politeknik Kesehatan Kemenkes Semarang, \\ Jl.Raya Baturaden KM 12 Purwokerto, Indonesia
}

\begin{abstract}
Abstrak
Penyakit Demam Berdarah adalaah penyakit yang disebabkan oleh virus Dengue, yang ditularkan oleh nyamuk Aedes aegypti. Berdasarkan laporan Puskesmas Purwokerto Selatan jumlah kasus DBD pada tahun 2016 tercatat 22 kasus.Tujuan penelitian ini adalah menggambarkan kondisi lingkungan fisik rumah penderita DBD antara lain pencahayaan, suhu, kelembaban, jenis tempat penampungaan air, dan kepadatan jentik (CI, HI, BI). Jumlah sampel adalah 16 orang penderita DBD di Kelurahan Teluk Kecamatan Purwokerto Selatan tahun 2017.Hasil penelitian terhadap 16 responden bahwa responden terbanyak adalah perempuan berjumlah 11 orang (69\%), berusia 11-20 tahun berjumlah 8 orang (50\%) dan 11 orang pelajar (69\%). Ketinggian tempat rata-rata 74 m diatas permukaan laut. Curah hujan 233 mm. pencahayaan rata-rata dalam rumah 61 Lux, bagian luar rumah 543 lux. suhu udara rata-rata bagian dalam rumah 330C, bagian luar rumah 340C. kelembaban udara bagian dalam rumah 56\%, bagian luar rumah 58\%. Jumlah container yang ditemukan 35 container dengan kepadatan jentik CI= $3,5 \%, H I=6,25 \%$, dan $B I=6,25 \%$. Jenis container yang ditemukan antara lain tempayan, bak mandi, ember, kolam ikan, pot, tempat minum burung, kulkas, dispenser, dan botol bekas. Kepadatan jentik CI memenuhi batas WHO, $(\leq 5 \%)$, H.I memenuhi batas WHO $(\leq 10 \%)$, B.I memenuhi batas WHO $(\leq 50 \%)$.Tetapi masyarakat juga harus rutin untuk membersihkan lingkungan rumah dan rutin membersihkan tempat penampugan air minimal seminggu sekali dan dinas kesehatan untuk tetap lebih aktif dalam menggalakkan kegiatan PSN di Kabupaten Banyumas agar kasus DBD di Kabupaten Banyumas dapat berkurang.
\end{abstract}

Kata kunci: lingkungan, fisik, rumah, $D B D$

\begin{abstract}
DESCRIPTION OF PHYSICAL HOUSE ENVIRONMENT FACTORS OF DHF IN TELUK VILAGE AT PURWOKERTO SELATAN DISTRICT OF BANYUMAS DISTRICT IN 2017 Dengue Hemorrhagic Fever (DHF) disease is an infection disease caused by Dengue virus transmitted primarily through bites of Aedes aegypti . Based on the Purwokerto Selatan Public Health Center repotrs the number of dengue cases incedence from January to December 2013 recorded 22 cases.The research is to describe the physical environment condition of DHF house such as ilumination, air temperatur, air humidity, kind of breeding place, and mosquito larva density (CI, HI, BI). The samples is 16 people with DHF in Teluk Village of Purwokerto selatan sub-district in 2017.The results show from 16 respondents that the highest number of respondents are women (11\%), 11-20 years old (8\%) and 11 students (69\%). Height of places average are 74 meters from surface of the sea. Rainfall $233 \mathrm{~mm}$. The average ilumination in the house 61 lux, part of the house 543 lux. Average air temperature part in the house 330C, part out of the house 340C.average air humidity 56\%, part of the house 58\%. Total containers was found 28 containers $\mathrm{CI}=3.5 \%, \mathrm{HI}=6.25 \%$, and $\mathrm{BI}=6.25 \%$.Kind of breeding place was found are jars, bathtubs, pail, fish ponds, pots, bird drinks, refrigerators, dispensers and bottles. The larval density of CI border fill from WHO, $(\leq 5 \%)$, border fill from WHO H.I $(\leq 10 \%)$, B.I border fill from WHO $(\leq 50 \%)$. But the community must also routine to clean the home environment and routine clean the water tank at least once a week, And health offices to remain more active in promoting PSN activities in Banyumas District in order to reduce dengue cases in Banyumas district.
\end{abstract}

Keywords: environment, physical, house, DHF

\footnotetext{
${ }^{*}$ E-mail : Rahmawidi96@gmail.com

${ }^{* *}$ E-mail : Choirul1960@gmail.com
} 


\section{Pendahuluan}

Menurut Undang-Undang Republik Indonesia nomor 36 Tahun 2009 tentang kesehatan pasal 162 menyebutkan bahwa upaya kesehatan lingkungan ditujukan untuk mewujudkan kualitas lingkungan yang sehat, baik fisik, kimia, biologi, maupun sosial serta memungkinkan setiap orang mencapai derajat kesehatan setinggi-tingginya. Dalam rangka mewujudkan derajat kesehatan, untuk pencegahan penularan penyakit menular wajib dilakukan oleh masyarakat termasuk penderita penyakit menular melalui perilaku hidup bersih dan sehat.

Lingkungan yang tidak sehat dan tidak seimbang akan memunculkan penyakit-penyakit yang berbasis lingkungan seperti : Demam Berdarah, Malaria, Diare, Cacingan, TB Paru dan penyakit berbasis lingkungan lainnya. Salah satu penyakit yang berbasis lingkungan dan memiliki angka kesakitan yang cukup tinggi yaitu Demam Berdarah Dengue (DBD) yang dapat bermanifestasi sebagai Dengue Shock Syndrome (DSS) merupakan penyakit menular tidak langsung.Cara penularannya melalui vektor nyamuk Aedes aegypti dan Aedes albopictus. Terutama nyamuk Aedes aegypti yang habitatnya berada di dalam dan di sekitar rumah. Penyakit DBD merupakan masalah kesehatan yang harus diwaspadai, karena sering menimbulkan wabah dan kematian terutama pada anak-anak.

Faktor yang mempengaruhi kejadian penyakit demam berdarah dengue antar lain faktor hospes (host), lingkungan (environment), dan agent. Faktor lingkungan fisik yaitu ( macam tempat penampungan air, curah hujan, kecepatan angin, pencahayaan, kelembaban, suhu, musim), dan kepadatan nyamuk sebagai vektor penular penyakit.(Soegeng Soegijanto;2006,h.11)

Kabupaten Banyumas dalam lima tahun terakhir jumlah kasus penderita DBD fluktuatif dengan data yang diperoleh dari dinas kesehatan kabupaten Banyumas sebagai berikut : Tahun 2011 sebanyak201 kasus $(I R=37,7)$, Tahun 2012 sebanyak 200 kasus $(I R=37,5)$, Tahun 2013 sebanyak543 kasus (101,9), Tahun 2014 sebanyak 209 kasus (IR=39,2), Tahun2015 sebanyak 264 kasus (IR=49,5)dan Tahun 2016 sebanyak 1281 kasus (IR=240,6). Peningkatan jumlah kasus secara drastis terjadi pada tahun 2016. (Profil Dinkes Kabupaten Banyumas Tahun 2016)

Berdasarkan data Dinas Kabupaten Banyumas Tahun 2016 Kecamatan Purwokerto selatan dengan jumlah penduduk 80.800 jiwa, merupakan wilayah yang endemis dan sering terjadi kasus DBD yaitu dengan distribusinya sebagai berikut: Karang Klesem 11 kasus (IR=1,36), Berkoh 9 Kasus (IR=1,11), Purwokerto Kidul 6 kasus (IR=0,74), Purwokerto Kulon 7 kasus (IR=0,86), Tanjung 21 kasus (IR=2,59), Karang Pucung 16 Kasus (IR=1,98), Teluk 23 kasus (IR=2,84).

Kelurahan Teluk terletak di sebelah selatan Kota Purwokerto dengan ketinggian $74 \mathrm{~m}$ diatas permukaan laut merupakan kelurahan dengan jumlah kasus yang paling tinggi pada tahun 2016. Dari penelitian sebelumnya didapatkan hasil bahwa di Kelurahan Teluk suhu udara dalam rumah penderita DBD yaitu $27^{\circ} \mathrm{C}$ dan kelembaban 62\%. Jika dilihat kondisi rumah di KelurahanTeluk sudah saniter tetapi rumah dengan lingkungan yang bersih pun masih terdapat faktor-faktor penyebab terjadinya kejadian DBD diantara adalah perilaku dari penghuni rumah yang suka menggantungkan pakaian di dinding, pintu dan jendela yang jarang dibuka sehingga dapat meningkatkan kelembaban didalam rumah. (Donei Ajian,2014)

Dari latar belakang tersebut diatas maka peneliti tertarik untuk melakukan penelitian tentang penyakit demam berdarah di Kelurahan Teluk Kecamatan Purwokerto Selatan dengan judul :"Gambaran Faktor Lingkungan Fisik Rumah Penderita DBD di Kelurahan Teluk Kecamatan Purwokerto Selatan Tahun 2017”.

\section{Bahan dan Metode}

Metode penelitian yang dilakukan adalah deskriptif yang bertujuan untuk menggambarkan faktor lingkungan fisik yang mempengaruhi terjadinya kejadian demam berdarah (DBD) di Kelurahan Teluk Kecamatan Purwokerto Selatan, Kabupaten Banyumas.

Pada penelitian ini adala mengukur faktor lingkungan fisik rumah seperti pengukuran pencahayaan, kelembaban, suhu, jenis tempat penampungan air dan kepadatan jentik

\section{Hasil}

Luas wilayah Kecamatan Purwokerto Selatan, Kabupaten Banyumas adalah 1375,31 Ha atau 13,75 $\mathrm{Km} 2$, terdiri dari tujuh kelurahan yaitu Kelurahan Tanjung (1,59 Km2), Kelurahan Karangpucung (1,48 Km2), Kelurahan Karangklesem (3,02 Km2), Kelurahan Teluk (3,51 Km2), Keluarahan Berkoh (1,86 Km2), Kelurahan Purwokerto Kidul (1,11 Km2), dan Kelurahan Purwokerto Kulon (1,18 Km2). Secara administrasi Kelurahan Teluk, terdiri dari 17 RW dan 97 RT. Jumlah penduduk Kelurahan Teluk Purwokerto Selatan tahun 2017 adalah 17.828 orang yang terdiri dari 8.995 orang penduduk laki- laki dan 8.833 orang penduduk perempuan.Keadaan Topografi berdasarkan data dari profil kelurahan Teluk bahwa Kelurahan Teluk berada pada ketinggian $74 \mathrm{~m}$ dari permukaan laut dengan rata-rata jumlah curah hujan tahunan $223 \mathrm{~mm}$.

Tabel 1. jumlah responden berdasarkan jenis kelamin di kelurahan teluk kecamatan purwokerto selatan tahun 2017

\begin{tabular}{cccc}
\hline No & Jenis kelamin & \multicolumn{2}{c}{ Kasus } \\
& & Jumlah & $\%$ \\
\hline 1 & Laki -laki & 5 & 31 \\
2 & Perempuan & 11 & 69 \\
\hline & Jumlah & 16 & 100 \\
\hline
\end{tabular}


Karakteristik responden berdasarkan jenis kelamin diketahui bahwa subyek kasus paling banyak adalah berjenis kelamin perempuan dengan persentase sebesar 69\% dari keseluruhan subyek kasus.

Tabel 2. jumlah responden berdasarkan umur di kelurahan teluk kecamatan purwokerto selatan tahun 2017

\begin{tabular}{cccc}
\hline No & $\begin{array}{c}\text { Umur } \\
\text { Responden } \\
\text { (Tahun) }\end{array}$ & $\begin{array}{c}\text { Kasus } \\
\text { Jumlah }\end{array}$ & $\%$ \\
\hline 1 & $1-10$ & 3 & 19 \\
2 & $11-20$ & 8 & 50 \\
3 & $21-30$ & 3 & 19 \\
4 & $31-40$ & 1 & 6 \\
5 & $41-50$ & 0 & 0 \\
6 & $51-60$ & 1 & 6 \\
\hline & Jumlah & 16 & 100 \\
\hline
\end{tabular}

Karakteristik responden berdasarkan golongan umur diketahui bahwa subyek kasus paling banyak berusia 11-20 tahun dengan persentase sebesar 50\% dari keseluruhan subyek kasus.

Tabel 3. jumlah responden berdasarkan pendidikan di kelurahan teluk kecamatan purwokerto selatan tahun 2017

\begin{tabular}{cccc}
\hline & Pendidikan & \multicolumn{2}{c}{ Kasus } \\
No & & Jumlah & $\%$ \\
\hline 1 & Belum sekolah & 1 & 6 \\
2 & SD & 3 & 19 \\
3 & SMP & 3 & 19 \\
4 & SMA/SMK & 5 & 31 \\
5 & DIII & 2 & 12 \\
6 & SI & 2 & 12 \\
\hline & Jumlah & 16 & 100 \\
\hline
\end{tabular}

Karakteristik responden berdasarkan tingkat pendidikan diketahui bahwa subyek kasus paling banyak terjadi pada tingkat pendidikan SMA/SMK dengan persentase sebesar 31\% dari keseluruhan subyek kasus.

Tabel 4. jumlah responden berdasarkan jenis pekerjaan di kelurahan teluk kecamatan purwokerto selatan tahun 2017

\begin{tabular}{cccc}
\hline No & Pekerjaan & \multicolumn{2}{c}{ Kasus } \\
& & Jumlah & $\%$ \\
\hline 1 & PNS & 1 & 6 \\
2 & Swasta & 6 & 38 \\
3 & Pelajar/ & 7 & 44 \\
& Mahasiswa & & \\
4 & Belum bekerja & 2 & 13 \\
\hline & Jumlah & 16 & 100 \\
\hline
\end{tabular}

Karakteristik responden berdasarkan jenis pekerjaan diketahui bahwa subyek kasus paling banyak terjadi pada responden dengan jenis pekerjaan Pelajar/Mahasiswa dengan persentase sebesar $44 \%$ dari keseluruhan subyek kasus

Tabel 5. Lingkungan fisik berdasarkan pencahayaan di kelurahan teluk kecamatan purwokerto selatan tahun 2017

\begin{tabular}{cc|c}
\hline $\begin{array}{c}\text { No } \\
\text { Responden }\end{array}$ & \multicolumn{2}{c}{$\begin{array}{c}\text { Pencahayaan } \\
\text { (lux) }\end{array}$} \\
& Dalam rumah & Luar rumah \\
\hline 1 & 55 & 272 \\
2 & 20 & 450 \\
3 & 63 & 606 \\
4 & 154 & 764 \\
5 & 98 & 420 \\
6 & 24 & 352 \\
7 & 43 & 442 \\
8 & 31 & 508 \\
9 & 72 & 142 \\
10 & 14 & 633 \\
11 & 92 & 111 \\
12 & 68 & 1204 \\
13 & 86 & 536 \\
14 & 126 & 1160 \\
15 & 32 & 635 \\
16 & 93 & 453 \\
\hline Jumlah & 61 Lux & 543 Lux \\
Rata-rata & & \\
\hline
\end{tabular}

Kondisi lingkungan fisik menurut pencahayaan diketahui bahwa rata- rata pencahyaan di Kelurahan Teluk Kecamatan Purwokerto Selatan untuk bagian dalam rumah adalah 61 Lux, sedangkan untuk bagian luar rumah adalah 543 Lux. Subyek tempat dengan ratarata pencahyaan tertinggi adalah rumah nomor 4 dengan pencahayaan bagian dalam rumah adalah 154 Lux dan pencahayaan luar rumah nomor 12 adalah 1204 Lux.

Tabel 6. Lingkungan fisik berdasarkan suhu di kelurahan teluk kecamatan purwokerto selatan tahun 2017

\begin{tabular}{cc|c}
\hline No & \multicolumn{2}{c}{ Suhu $\left({ }^{0} \mathrm{C}\right)$} \\
Responden & Dalam rumah & Luar rumah \\
\cline { 1 - 2 } 1 & 34 & 34 \\
2 & 33 & 34 \\
3 & 33 & 33 \\
4 & 34 & 36 \\
5 & 33 & 33 \\
6 & 34 & 35 \\
7 & 32 & 35 \\
8 & 32 & 33 \\
9 & 34 & 32 \\
\hline
\end{tabular}




\begin{tabular}{cc|c}
\hline 10 & 33 & 33 \\
11 & 33 & 35 \\
12 & 32 & 34 \\
13 & 32 & 34 \\
14 & 34 & 33 \\
15 & 34 & 36 \\
16 & 31 & 34 \\
\hline Jumlah & $33^{0} \mathrm{C}$ & $34^{0} \mathrm{C}$ \\
Rata-rata & & \\
\hline
\end{tabular}

Kondisi lingkungan fisik menurut suhu diketahui bahwa rata- rata suhu di Kelurahan Teluk Kecamatan Purwokerto Selatan untuk bagian dalam rumah adalah $33^{\circ} \mathrm{C}$, sedangkan untuk bagian luar rumah adalah $34^{0} \mathrm{C}$.

Tabel 7. Lingkungan fisik berdasarkan kelembaban di kelurahan teluk kecamatan purwokerto selatan tahun 2017

\begin{tabular}{ccc}
\hline $\begin{array}{c}\text { No } \\
\text { Responden }\end{array}$ & \multicolumn{2}{c}{$\begin{array}{c}\text { Kelembaban } \\
(\%)\end{array}$} \\
& Dalam rumah & Luar rumah \\
\hline 1 & 48 & 50 \\
2 & 52 & 60 \\
3 & 58 & 58 \\
4 & 60 & 60 \\
5 & 48 & 52 \\
6 & 54 & 56 \\
7 & 62 & 62 \\
8 & 56 & 60 \\
9 & 52 & 56 \\
10 & 54 & 60 \\
11 & 62 & 62 \\
12 & 64 & 64 \\
13 & 60 & 60 \\
14 & 48 & 52 \\
15 & 60 & 60 \\
16 & 62 & 62 \\
\hline Jumlah & $56 \%$ & $58 \%$ \\
Rata-rata & & \\
\hline
\end{tabular}

Kondisi lingkungan fisik menurut kelembabandiketahui bahwa rata- rata suhu di Kelurahan Teluk Kecamatan Purwokerto Selatan untuk bagian dalam rumah adalah 56\%, sedangkan untuk bagian luar rumah adalah 58\%. Subyek tempat dengan rata- rata kelembaban tertinggi adalah rumah nomor 12 dengan kelembaban bagian dalam rumah adalah 64\% dan kelembaban luar rumah 64\%.

\section{Pembahasan}

Kelurahan Teluk adalah salah satu Kelurahan yang ada pada Kecamatan Purwokerto Selatan yang memiliki luas wilayah paling besar diantara 6 Desa lainnya yaitu seluas 3,51 Km2. Secara administrasi Kelurahan Teluk terbagi menjadi 17 RW dan 97 RT dengan batas wilayahnya yaitu sebelah utara berbatasan dengan Purwokerto Kulon, sebelah Selatan berbatasan dengan Kedung Randu, sebelah Timur berbatasan dengan Karang Nanas, dan sebelah Barat berbatasan dengan Karagklesem.

Jumlah penduduk Kelurahan Teluk tahun 2017 adalah 17.828 orang dengan jumlah penduduk laki- laki lebih banyak yaitu 8.995 jiwa sedangkan jumlah penduduk perempuan 8.833 jiwa.

Kelurahan Teluk terletak pada ketinggian $74 \mathrm{~m}$ dari permukaan laut. Dengan curah hujan $233 \mathrm{~mm} / \mathrm{tahun}$ dengan suhu rata-rata $34^{\circ} \mathrm{C}$. Ketinggian tempat dapat mempengaruhi penyebaran nyamuk, saat musim hujan akan menambah banyak genangan air yang dapat digunakan sebagai tempat perkembangbiakan nyamuk. Suhu dan kelembaban saat musim hujan akan sangat mempengaruhi kelangsungan hidup nyamuk. Suhu optimum untuk pertumbuhan nyamuk adalah dari $25^{\circ} \mathrm{C}$ $27^{\circ} \mathrm{C}$ dan kelembaban optimum untuk pertumbuhan nyamuk adalah dari 60\%- 80\%. Sehingga dapat menyebabkan terjadinya penularan suatu penyakit salah satunya dalah penyakit DBD.

Responden pada penelitian ini adalah penderita Demam Berdarah Dengue di Kelurahan Teluk Kecamatan Purwokerto Selatan pada bulan Januari sampai Desember tahun 2016 yang berjumlah 22 orang. Dalam penelitian ini diambil seluruh obyek penelitian yang berjumlah 22 orang. Pada kegiatan survei pengumpulan data hanya 16 rumah yang dapat di survei sedangkan 6 rumah tidak dapat di survei. Karena ada beberapa faktor yang mempengaruhi diantaranya adalah responden tidak berada diirumah saat kegiatan survei pengumpulan data, responden tidak bersedia untuk menjadi responden saat kegiatan survei pengumpulan data dan kesalahan awal pada data alamat responden sehingga peneliti tidak menemukan rumah responden.

a. Jumlah responden berdasarkan jenis kelamin jumlah kasus penderita penyakit Demam Berdarah Dengue dengan jumlah penderita perempuan lebih tinggi yaitu sebanyak 11 orang dengan persentase 69\% dan penderita laki-laki sebanyak 5 orang dengan persentase $31 \%$. subyek penderita perempuan lebih tinggi karena penderita banyak melakukan aktivitas dari pagi sampai sore hari, kebiasaan menggantung pakaian dan penderita pernah bepergian ke tempat yang berpotensi sebagai penular penyakit salah satunya penyakit DBD.

b. Jumlah responden berdasarkan jenis kelamin jumlah kasus pederita penyakit Demam Berdarah Dengue umur 1-10 tahun berjumlah 3 orang, umur 1120 tahun berjumlah 8 orang, umur 21-30 tahun berjumlah 3 orang, umur 31-40 tahun berjumlah 1 orang, umur 41-50 tahun berjumlah 0, dan umur 51-60 tahun berjumlah 1 orang. Diketahui jumlah kasus penderita DBD paling banyak adalah responden dengan rentang umur 11-20 tahun sebanyak 8 orang dengan persentase $50 \%$ dan jumlah kasus penderita DBD paling sedikit atau tidak ditemukan kasus pada 
responden dengan rentang umur 41-50 tahun. Tingginya jumlah kasus pada responden umur 11-20 tahun karena usia remaja adalah usia yang produktif dalam melakukan aktivitas, yang dapat mempermudah dalam penularan penyakit salah satunya penyakit Demam Berdarah Dengue.

c. Jumlah responden berdasarkan jenis pendidikan jumlah kasus penderita Demam Berdarah Dengue dengan tingkat pendidikan belum sekolah berjumlah 1 kasus, SD/sederajat berjulah 3 kasus, SMP/sederajat berjumlah 3 kasus, SMS/SMK Sederajat berjumlah 5 kasus, DIII berjumlah 2 kasus, dan S1 berjumlah 2 kasus. Diketahui jumlah kasus penderita DBD tertinggi adalah responden dengan tingkat pendidikan SMA/SMK sederajat dengan persentase 31\%. Tingginya jumlahkasus pada responden dengan tingkat pendidikan SMA/SMK sederajat karena usia produktif dalam melakukan aktivitas sehingga mempermudah dalam penularan peyakit. Tingkat pendidikan juga sangat mempengaruhi perilaku dan cara berfikir dalam menerima penyuluhan tentang cara pemberantasan penyakit.

d. Jumlah responden berdasarkan jenis pekerjaan jumlah kasus penderita Deman Berdarah Dengue dengan jenis pekerjaan PNS berjumlah 1 kasus, Swasta berjumlah 6 kasus, pelajar/mahasiswa berjumlah 7 kasus, belum bekerja berjumlah 2 kasus. Diketahui jumlah kasus penderita DBD teringgi adalah responden dengan jenis pekerjaan Pelajar/Mahasiswa dengan persentase $44 \%$. Pekerjaan adalah aktivitas utama yang dilakukan untuk melaksanakan suatu tugas atau kerja yang dapat menghasilkan uang. Pekerjaan juga sebagai penunjang manusia untuk melakukan aktivitas ditempat kerja yang tanpa diketahui bahwa tempat pekerjaan tersebut dapat berpotensi sebagai salah satu faktor penular penyakit salah satunya adalah penyakit DBD.

e. Pencahayaan

kasus penderita Demam Berdarah Dengue dengan kondisi lingkungan fisik menurut pencahayaan dengan rata-rata pencahayaan didalam rumah adalah 61 Lux dan diluar rumah adalah 543 Lux.

Nyamuk Aedes sp bersifat diurnal atau aktif pada pagi hingga siang hari pada pikul 08.00 - 12.00 dan sore hari pada pukul 15.00 - 17.00. Nyamuk Aedes biasa beristirahat pada tempat-tempat gelap seperti pada kolong tempat tidur atau pada benda-benda yang menggantung didalam rumah, karena tempat- tempat gelap cenderung memiliki suhu dan kelembaban yang sesuai untuk siklus pertumbuhan nyamuk.

\section{f. Suhu}

kasus penderita Demam Bedarah Dengue dengan kondisi lingkungan fisik menurut suhu dengan rata-rata suhu didalam rumah $33^{\circ} \mathrm{C}$ dan diluar rumah adalah $34^{0} \mathrm{C}$.
Nyamuk dapat bertahan hidup pada suhu rendah tetapi metabolisme nyamuk akan menurun. Sebaliknya, nyamuk pada suhu tinggi juga akan menglami perubahan fisiologis. Nyamuk dapat bertahan hidup pada suhu optimum yaitu pada $25^{\circ} \mathrm{C}-27^{\circ} \mathrm{C}$. Pertumbuhan nyamuk akan terlambat atau bahkan terhenti apabila suhu kurang dari $10^{\circ} \mathrm{C}$ atau lebih dari $40^{\circ} \mathrm{C}$.

g. Kelembaban

Kasus penderita Demam Berdarah Dengue dengan kondisi ingkungan fisik menurut kelembaban dengan rata-rata kelembaban didalam rumah 56\% dan diluar rumah adalah 58\%.

Nyamuk biasa beristirahat pada tempat-tempat gelap seperti pada kolong tempat tidur, karena tempat tempat gelap cenderung memiliki kelembaban yang tinggi kelembaban optimum untuk pertumbuhan nyamuk adalah $60 \%-80 \%$.

h. Tempat penampungan air

Kasus penderita Demam Berdarah Dengue dengan kondisi lingkungan fisik menurut tempat penampungan air ditemukan sebanyak 35 container yang berpotensi sebagai tempat perindukan nyamuk. Dari 35 container ditemukan 1 container yang positif ditemukan keberadaan jentik. Container tersebut adalah tempat penampungan air di belakang kulkas.Tempat tersebut dapat dikatakan container karena keberadaannya yang tergenang air dan container tersebut berada pada tempat yang lembab dan gelap serta jarang dibersihan oleh masyarakat. Sehingga tempat tersebut menjadi tempat yang potensial bagi nyamuk Aedes untuk bertelur sehingga ditemukan adanya jentik yang berpotensi menjadi tempat perkembangbiakan nyamuk.

i. Kepadatan jentik

Hasil kegiatan survei yang dilakukan di Kelurahan Teluk dengan subyek sebanyak 16 rumah didapatkan hasil Container Indeks (CI) adalah 2,8\%. Menurut WHO bahwa batas $\mathrm{CI}$ adalah $\leq 5 \%$, sehingga dapat dikatakan memenuhi syarat karena container yang ditemukan positif jentik kurang/ sama dengan 5\%. Untuk Breteau Indeks (B.I) ditemukan hasil 6,25\%, dan menurut WHO hasil tersebut sudah memenuhi syarat karena hasil yang didapat $\leq 50 \%$. Untuk House Indeks (HI) didapatkan hasil 6,25\%, dan menurut WHO bahwa batas $\mathrm{HI}$ adalah $\leq 10 \%$, sehingga dapat dikatakan memenuhi syarat karena hasil yang didapat kurang/ sama dengan 10\%. Dari hasil perhitungan CI, BI dan HI menurut WHO sudah memenuhi syarat, tetapi masih terdapat beberapa tempat penampungan air yang positif jentik, maka diharapkan untuk masyarakat untuk rutin membersihkan tempat penampungan air minimal seminggu sekali.

\section{Kesimpulan}

Dari hasil data yang telah dikumpulkan melaui kegiatan survei yang dilakukan di Kelurahan Teluk 
Kecamatan Purwokerto Selatan dengan jumlah subyek keseluruhan sebanyak 16 rumah didapatkan hasil sebagi berikut :

a. Rata -rata kelembaban udara di Kelurahan Teluk Kecamatan Purwokerto Selatan bagian dalam rumah adalah $56 \%$ dan bagian luar rumah adalah $64 \%$.

b. Rata-rata suhu udara di Kelurahan Teluk Kecamatan Purwokerto Selatan bagian dalam rumah adalah $33^{\circ} \mathrm{C}$ dan bagian luar rumah adalah $34^{\circ} \mathrm{C}$.

c. Rata-rata pencahayaan di Kelurahan Teluk Kecamatan Purwokerto Selatan bagian dalam rumah adalah 61 Lux dan bagian luar rumah adalah 543 Lux.

d. Jumlah tempat penampungan air yang diperiksa di Kelurahan Teluk Kecamatan Purwokerto Selatan sebanyak 35 container yang terdiri dari bak mandi, ember, kulkas, dispenser, kolam ikan, pot, tempat makan burung dan barang-barang bekas

e. Container Indeks (CI) Menurut WHO adalah $\leq$ $5 \%$, dan hasil yang didapat dari kegiatan survei di Kelurahan Teluk Kecamatan Purwokerto Selatan adalah 2,8\% sehingga dikatakan memenuhi syarat karena container yang positif jentik kurang/ sama dengan $5 \%$.

f. Breateu Indeks (BI) Menurut WHO adalah $\leq$ $10 \%$, dan hasil yang didapat dari kegiatan survei di Kelurahan Teluk Kecamatan Purwokerto Selatan adalah 6,25\% sehingga dikatakan memenuhi syarat karena container yang positif jentik kurang/ sama dengan $10 \%$.

g. House Indeks (HI) Menurut WHO adalah $\leq$ $10 \%$, dan hasil yang didapat dari kegiatan survei di Kelurahan Teluk Kecamatan Purwokerto Selatan adalah 6,25\% sehingga dikatakan memenuhi syarat karena container yang positif jentik kurang/ sama dengan $10 \%$.

\section{Saran}

Kepada Dinas Kesehatan Kabupaten Banyumas diharapkan untuk Dinas Kesehatan Kabupaten Banyumas lebih aktif dalam menggalakan kegiatan pemberantasan sarang nyamuk di desa-desa seluruh kabupaten Banyumas, agar kasus DBD di Kabupaten Banyumas dapat berkurang.

Kepada Kader PSN DBD diharapkan untuk Kader PSN di Desa Teluk Kecamatan Purwokero selatan untuk rutin melakukan kegiatan pemberantasan sarang nyamuk minimal seminggu sekali, sehingga tidak hanya diakukan pada saat terjadi KLB.

Kepada Masyarakat diharapkan selalu menjaga kebersihan lingkungan rumah, tidak menggantung pakaian di belakang pintu atau ditembok, rajin membersihkan tempat penampungan air seperti bak mandi dan tempat makan burung minimal seminggu sekali, serta mengubur barang-barang bekas yang berpotensi sebagai tempat perindukan nyamuk.

\section{Ucapan Terima Kasih}

Dalam penyelesaian karya tulis ilmiah ini penulis banyak mendapat bantuan baik materil maupun moril berbagai pihak, untuk itu penulis mengucapkan terima kasih kepada :

a. Bapak Sugiyanto, S.Pd., M.App., Sc, selaku Direktur Politeknik kesehatan Kemenkes Semarang.

b. Bapak Asep Tata Gunawan, S.KM., M.Kes, selaku Ketua Jurusan Kesehatan Lingkungan Purwokerto.

c. Bapak Suparmin, SST., M.Kes, selaku Ketua Progam Studi Diploma III Jurusan Kesehatan Lingkungan Purwokerto.

d. Bapak Dr.Choiroel Anwar, S.KM., M.Kes, selaku pembimbing yang telah banyak memeberikan bimbingan dan saran

e. Seluruh Dosen dan Staf Program Studi D-III Kesehatan Lingkungan Purwokerto yang telah membantu kelancaran penulisan Karya Tulis ilmiah

f. Ibu dan Bapak tercinta, Adik-adiku tersayang Rima dan Rossa yang telah memberikan dukungan, semangat, moitivasi serta doa sehingga lancar dalam penyusunan karya tulis imliah ini.

g. Estriana teman satu pembimbing dan satu penelitian, yang sudah banyak membantu memberikan dukungan baik moril maupun materi

h. Sahabat sahabat saya Niken, Dyar, Ayu, Risky, Astri yang sudah menjadi sahabat tebaik saya, yang mau mendengarkan keluh kesah saya dan yang selalu memberikan dukungan, semangat, doa dalam menyusun karya tulis ilmiah.

i. Dan lain-lain yang tidak dapat disebut satu persatu. Yang sudah membantu kelancaran penulis dalam menulis karya tulis ilmiah.

\section{Daftar Pustaka}

Badan Pusat Statistik Kabupaten Banyumas, 2016, Kabupaten Purwokerto Selatan Dalam Angka Tahun 2016, Banyumas: Badan Pusat Statistik Kabupaten Banyumas.

Budiman candra, 2005, pengantar kesehatan lingkungan,Jakarta, Buku kedokteran egc.

Cecep Dani Sucipto, 2011, Vektor Penyakit Tropis, Yogyakarta: Gosyen Publishing

Departemen Kesehatan R.I. Direktorat Jenderal Pengendalian Penyakit Dan Penyehatan Lingkungan (DIT.JEN. PP \& PL), 2007, survey entomologi Demam Berdarah Dengue, Jakarta : DIT.JEN. PP \& PL

Devi Farah Ghina, 2016, Hubungan faktor- faktor lingkungan fisik rumah dengan kejadian penyakit 
Demam Berdarah (DBD) di wilayah Puskesmas Cilacap Selatan II Kabupaten Cilacap Tahun 2016, Purwokerto : Kemenkes RI Politeknik Kesehatan Semarang Jurusan Kesehatan Lingkungan Purwokerto

Donei Ajian Veronica, 2014, Studi Faktor-Faktor lingkungan Fisik rumah penderita DBD Di wilayah kerja puskesmas selatan kabupaten Banyumas Tahun 2014, Purwokerto : Kemenkes RI Politeknik Kesehatan Semarang Jurusan Kesehatan Lingkungan Purwokerto

Irna Uswatul Hasanah, 2012, Faktor-Faktor Lingkungan Fisik Rumah yang Berhubungan dengan Kejadian Penyakit DBD Di Wilayah Puskesmas Banjarnegara I Kabupaten Banjarnegara Tahun 2012, Purwokerto : Kemenkes RI Politeknik Kesehatan Semarang Jurusan Kesehatan Lingkungan Purwokerto

Kementerian kesehatan Republik Indonesia Direktorat Jendral pengendalian penyakit dan penyehatan lingkungan, 2013, pedoman pengendalian Demam Berdarah Dengue di Indonesia, Jakarta

Peraturan Menteri Kesehatan Republik Indonesia Nomor 13, 2015, penyelenggaraan pelayanan kesehatan lingkungan di puskesmas

Ratna Pramuditya, 2014, Deskripsi Pemeberantasan Srang Nyamuk (PSN) DBD di Kelurahan Karangpucung Kecamatan Purwokerto Selatan Kabupaten Banyumas Tahun 2014: Kemenkes RI Politeknik Kesehatan Semarang Jurusan Kesehatan Lingkungan Purwokerto

Soegeng Suegijanto, 2006, Demam Berdarah Dengue Edisi kedua, Surabaya, Airlangga University

Tri Cahyono, 2012, Pedoman Penulisan Proposal Penelitian Dan Karya Tulis Ilmiah/ Skripsi Edisi Revisi Ketiga , Purwokerto : Kemenkes RI Politeknik Kesehatan Semarang Jurusan Kesehatan Lingkungan Purwokerto

Undang - undang Republik Indonesia nomor 36, 2009, tentang Kesehatan 